\title{
Progress Toward a Safer Future Since the 1989 Loma Prieta Earthquake
}

The 1989 Loma Prieta earthquake interrupted several decades of seismic tranquility in the San Francisco Bay Area. It caused damage throughout the region and was a wakeup call to prepare for potentially even more damaging future quakes. Since 1989, the work of the U.S. Geological Survey and many other organizations has improved the understanding of the seismic threat in the Bay Area, promoted awareness of earthquake hazards, and contributed to more effective strategies to reduce earthquake losses. These collective efforts will help reduce the impact of future large earthquakes in the Bay Area.

Just minutes before the start of the third game of the 1989 World Series in San Francisco, a magnitude 6.9 earthquake rocked Northern California from Monterey to San Francisco. Centered near Loma Prieta peak in the Santa Cruz Mountains south of San Jose, the quake killed at least 63 people and hospitalized another 350. It destroyed a freeway viaduct in Oakland, dropped a span of the Bay Bridge, collapsed historic buildings in Santa Cruz and apartment buildings in the Marina District

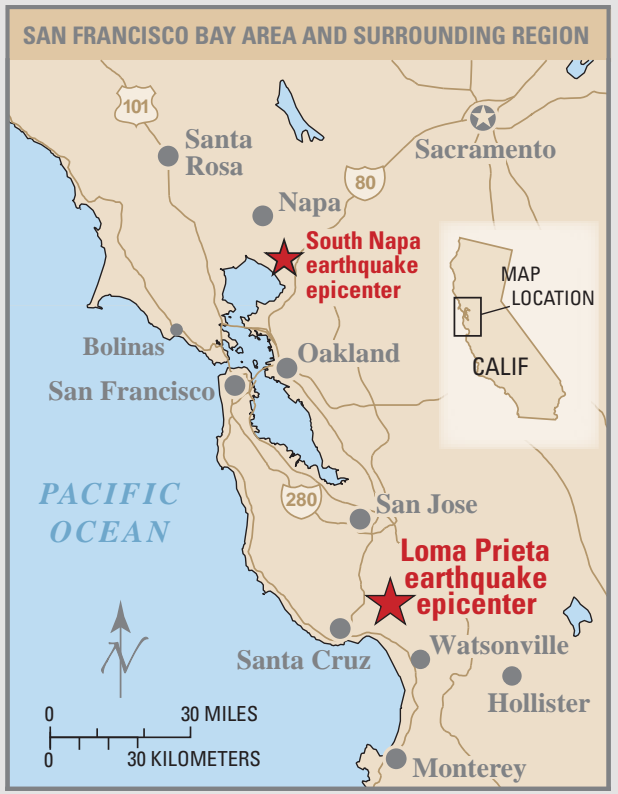

U.S. Department of the Interior U.S. Geological Survey

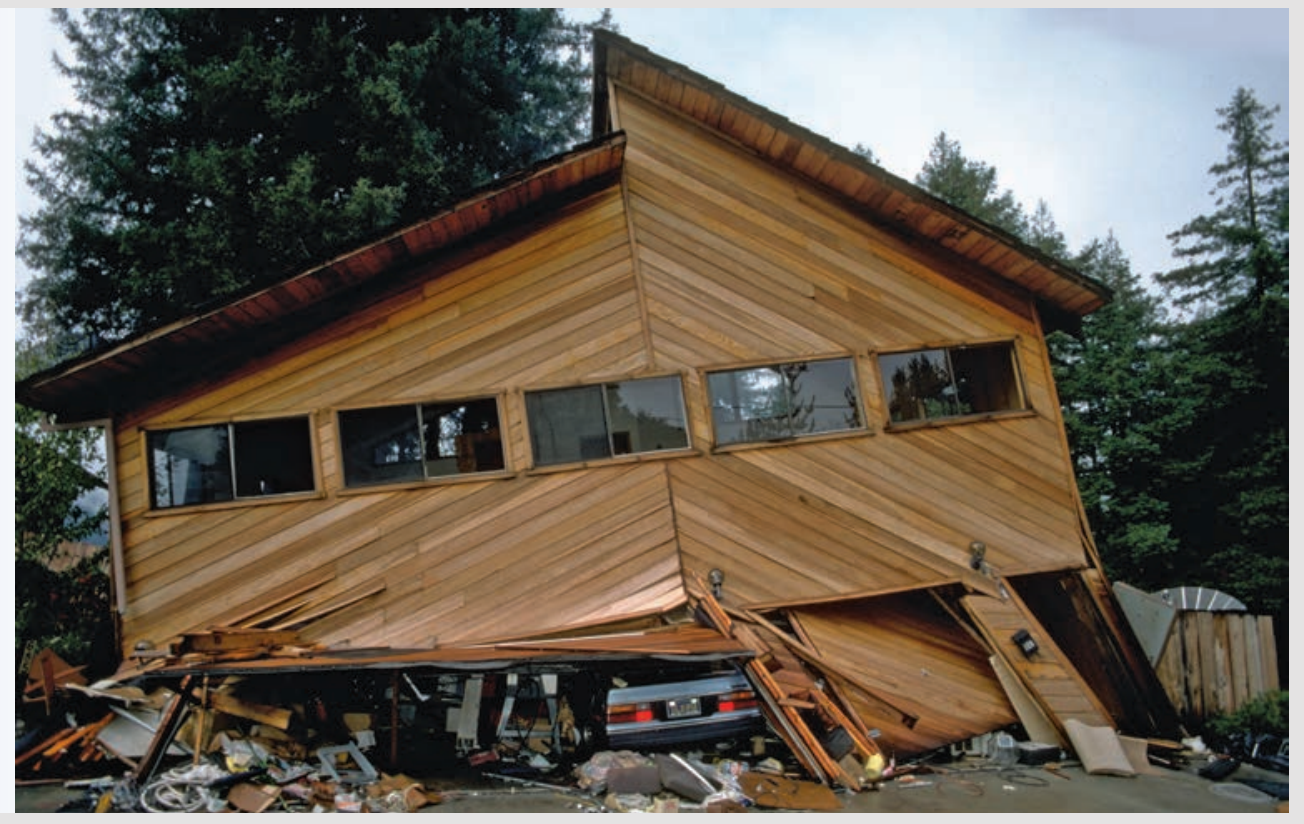

This house in the mountains north of Santa Cruz, California, was destroyed by the October 17, 1989, Loma Prieta earthquake. Shaking here, close to the epicenter of the magnitude 6.9 shock, was intense, and the house had inadequate support in its first story.

in San Francisco, severed communications, and caused an estimated $\$ 6$ to $\$ 10$ billion in property loss. It was the largest temblor to jolt the Bay Area since the Great San Francisco Earthquake of 1906 (magnitude 7.9).

Although the Loma Prieta earthquake struck on the outskirts of the region, it exposed the vulnerability of the Bay Area to future earthquakes - a vulnerability that was reemphasized on August 24, 2014, when a magnitude 6.0 earthquake occurred near Napa, California, about 30 miles north-northeast of San Francisco. At least 200 people were treated for quake-related injuries, and initial economic losses are estimated to be at minimum \$362 million. Some future earthquakes will certainly be larger and closer to the Bay Area's urban core than the 1989 and 2014 earthquakes.

Since the Loma Prieta earthquake, many organizations, including the U.S. Geological Survey (USGS), have redoubled efforts to understand earthquake hazards in urban areas and to apply this new knowledge to reduce future losses. The most hazardous areas have been extensively mapped and analyzed, and the most vulnerable structures have been retrofit or rebuilt. The USGS estimates that Bay Area agencies and businesses have invested over $\$ 30$ billion to retrofit or replace bridges, pipelines, hospitals, municipal buildings, and other infrastructure to make them more earthquake resilient and to reduce the time needed to recover from future Bay Area earthquakes. Communication of earthquake-hazard information to the public, to businesses, and to government agencies has also been strengthened.

\section{Earthquake Likelihood}

Even before the 1989 Loma Prieta shock, panels of scientists regularly reassessed the earthquake threat to the San Francisco Bay Area. They currently assign 2-in-3 odds that one or more destructive earthquakes (magnitude 6.7 or larger) will strike the Bay Area in the next 30 years.

Studies conducted since 1989 have added much new information for determining earthquake probabilities. Using information from airborne laser imagery of the Earth (in which vegetation was digitally removed), geologists have refined maps of earthquake faults. They have uncovered new evidence for the dates and amounts of slip of prehistoric earthquakes on the Hayward, San Andreas, 


\section{Ground Failure}

Ground failure — rock falls, landslides, and liquefaction — can locally be more damaging during an earthquake than shaking alone. About 2 percent of the total earthquakerelated losses during Loma Prieta were caused by ground failure. Rocks may fall from cliffs, steep slopes may slide, earth may flow downslope, and even flat ground may crack and tilt. Landslides of all shapes and sizes can block roads and damage buildings and neighborhoods.

When shaken strongly, unconsolidated sandy deposits that are saturated with water can liquefy and form a slurry. Liquefied sands cannot resist flowing downslope even on nearly flat ground, and cannot support the weight of man-made structures. As a result, liquefaction may result in sinking, tilt, distortion, or destruction of buildings and bridges, rupture of underground gas lines and water mains, and cracking and lateral spreading of the ground surface. During the Loma Prieta earthquake, loosely compacted sandy deposits and artificial fills liquefied at many locations around the margins of San Francisco and Monterey Bays and in adjacent riverbeds. Had the quake been larger or closer to the heavily developed margin of San Francisco Bay, the damage from liquefaction would have been far greater. Since 1989, the USGS has partnered with Federal Emergency Management Agency, Pacific Gas and Electric Company, the San Francisco Public Utility Commission, the City of Oakland, and other agencies to map areas where damaging liquefaction can occur.

\section{Near-Real-Time Earthquake Information}

After the Loma Prieta earthquake, managers of earthquake-monitoring networks in California agreed to combine their data in real time, thereby creating the California Integrated Seismic Network (CISN). The CISN reports within minutes earthquake locations, magnitudes, and ShakeMaps, which show the patterns of shaking across the region, helping community leaders organize emergency crews and relief efforts. ShakeMaps are particularly valuable in the Bay Area, where the wide variety of geologic materials - from hard bedrock to soft clay—causes large differences in shaking intensity. The USGS also maps the levels of shaking in different parts of the Bay Area as reported by online respondents through the "Did you feel it?" Web site and can therefore assess the local intensity of an earthquake independently of ShakeMap. Both maps help emergency responders to rapidly identify locations where damage and need are likely to be greatest.
In 2005, the USGS partnered with the California Department of Transportation (DOT) to produce ShakeCast, an application that uses ShakeMaps and DOT-supplied estimates of the likelihood that a level of shaking will cause damage to a particular structure to prioritize DOT's inspection of bridges following earthquakes. Many other agencies also use ShakeCast to prioritize inspections of their facilities after earthquakes.

In 2010, the USGS released PAGER (Prompt Assessment of Global Earthquakes for Response), an alert that rapidly estimates fatalities and economic losses for earthquakes. To make these loss projections, PAGER uses ShakeMaps of the earthquake, global census data, and estimates of the likelihood that the building stock in the impacted region can withstand strong shaking (http:// pubs.usgs.gov/fs/2010/3036/). PAGER assigns a color code to each potentially damaging earthquake to indicate the level of emergency response the earthquake will require.

Significant strides have been made in making earthquake information available faster.

Digital seismic instruments now used in the networks report their data within a second, reducing the time for earthquakes to be detected. In fact, advances in technology now permit the computation of earthquake locations and magnitudes within seconds so that notifications can be broadcast to some areas that have not yet undergone shaking from an earthquake - this forms the basis for the Earthquake Early Warning System, which is being developed by the USGS, the University of California at Berkeley, the California Institute of Technology (Caltech), and the University of Washington. It will send alerts to the public and community managers ahead of strong shaking, so that a variety of actions can be taken, such as opening firehouse doors, stopping trains, and taking cover.

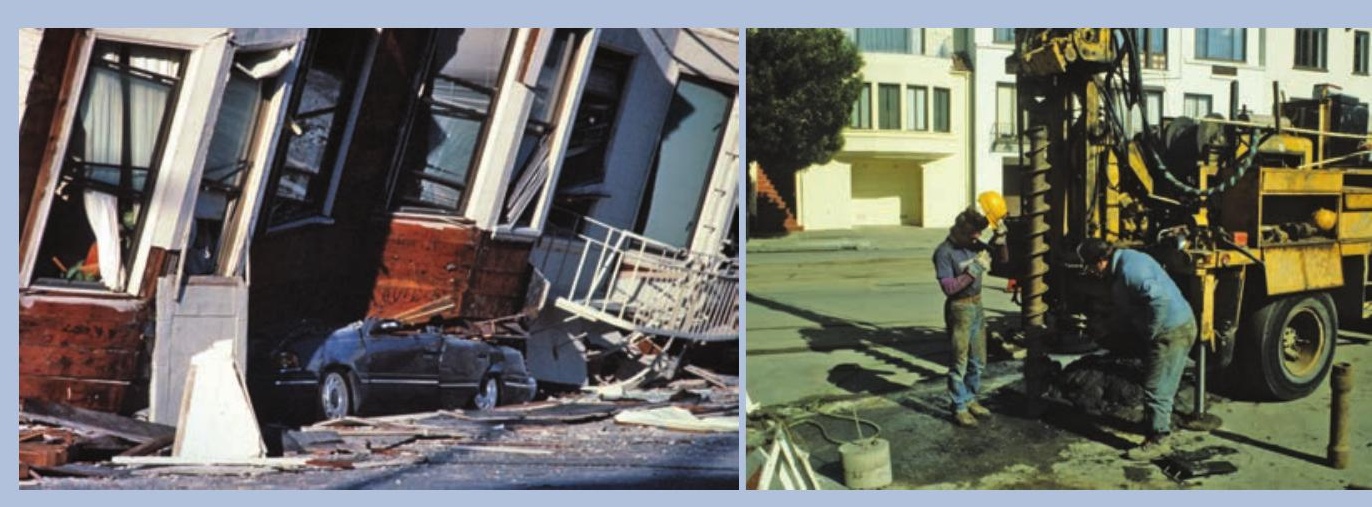

The Marina District of San Francisco was heavily damaged in the 1989 Loma Prieta earthquake (left) because it was built on uncompacted, sandy ground in an area with a shallow water table. These conditions caused shaking to be amplified and some areas of ground to liquefy. Shaking collapsed the first story of many apartment buildings and liquefied the ground beneath the sidewalk, causing it to buckle. In the weeks following the quake, the U.S. Geological Survey drill rig shown at right was used to gather subsurface samples so that the causes of liquefaction could be better understood. (USGS photographs by J.K. Nakata and T. Holzer.) 

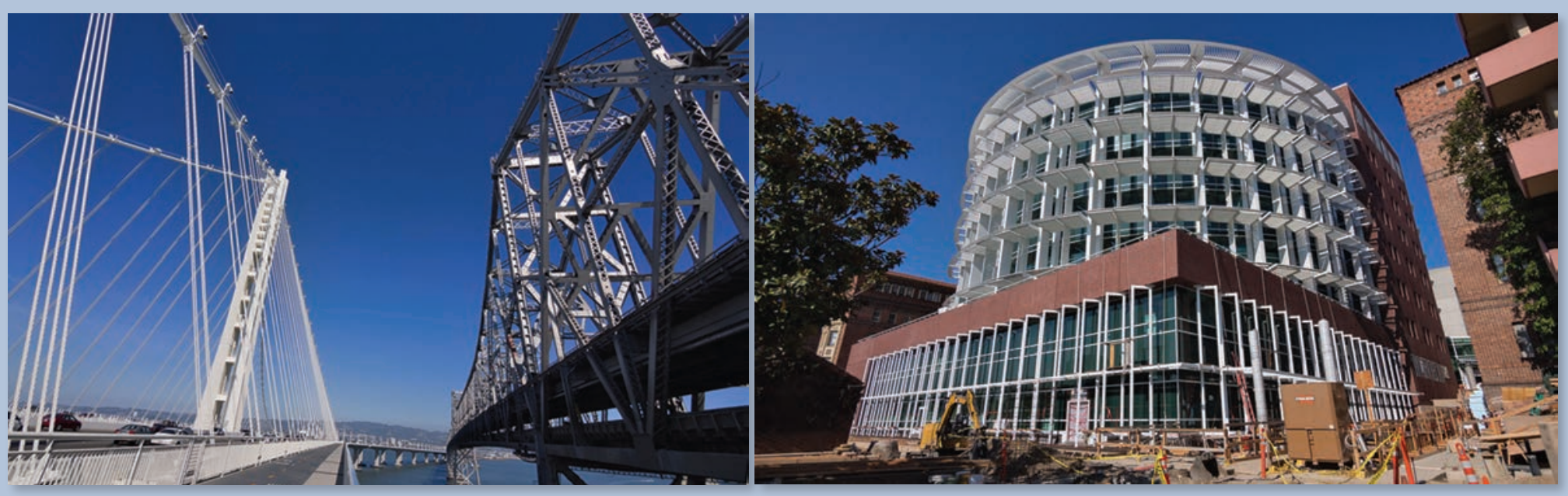

Since the 1989 Loma Prieta earthquake, many iconic structures around the Bay Area-including San Francisco City Hall, the Ferry Building, the Golden Gate Bridge, San Francisco General Hospital (above right), and the eastern span of the Bay Bridge (above left; disassembly shown in front banner)—have been replaced or retrofit with earthquake-resistant support so that they may remain intact in the event of a large earthquake. (USGS photographs by $S$. Haefner.)

\section{Earthquake Scenarios and Preparedness}

Although scientists cannot predict exactly when destructive earthquakes will occur, they can estimate the damaging effects of a potential earthquake of a given size and, together with engineers, assess the expected property damage and loss of life. Emergency-response managers, government agencies, corporate planners, and private citizens use such assessments to reduce the risk of losses and to plan for response and recovery after a large quake. USGS scientists are working with numerous agencies and organizations to estimate the possible impacts of future earthquakes at both regional and national scales, including scenarios for response exercises for an earthquake on the Hayward Fault and a repeat of the 1906 San Francisco Earthquake.

In 2009, the USGS founded the Bay Area Earthquake Alliance, a public-private partnership that promotes earthquake awareness and mitigation in the region, and which annually cosponsors the Great California ShakeOut earthquake preparedness exercise held on the third Thursday of October. Nearly 10 million Californians participate in this annual exercise.

The regional infrastructure's poor performance during the Loma Prieta earthquake, coupled with USGS earthquake hazard models, has led several municipalities to require the mandatory retrofit of collapseprone unreinforced masonry buildings and of "soft-story" buildings. So called because of inadequate support in their first story, collapses of soft-story buildings were prominent in San Francisco's Marina District during the Loma Prieta earthquake.

The USGS has also partnered with local agencies to assess the dangers to the utilities and transportation corridors around the San Francisco Bay Area. With the San Francisco Public Utility Commission, the USGS mapped the precise location of the San Andreas Fault so that the retrofit of the Hetch Hetchy Aqueduct and water conveyance systems on the San Francisco Peninsula were more resilient. The USGS and Bay Area Rapid Transit (BART), which operates a public rail transit system, estimated the amount of slip that would likely be produced by an earthquake on the Hayward Fault and how it would affect BART's tunnels crossing the fault.

\section{Communicating Earthquake Hazards}

Comprehensive studies of the Loma Prieta earthquake and its impacts were collected in a set of four USGS Professional Papers that are available online at http://earthquake.usgs.gov/ regional/nca/1989/papers.php. These reports describe the earthquake, the ground shaking and ground failures that it produced, the performance of buildings and other man-made structures, and the societal response to the earthquake.

Since the 1989 Loma Prieta earthquake, the USGS has increased its efforts to better communicate earthquake-hazard information to a broad audience. USGS scientists regularly participate in media events, conferences, and earthquake-preparedness fairs. The USGS and several cooperators, with financial support from the California Earthquake Authority, American Red Cross, and Pacific Gas and Electric Company, produced a popular educational booklet called "Putting Down Roots in Earthquake Country.” The booklet has been translated into Spanish, Chinese, Vietnamese, and Korean in editions entitled "Protecting Your Family from Earthquakes.” All versions are available online at http://earthquake.usgs. gov/regional/nca/prepare/index.php. These booklets have been emulated in other highly active seismic regions in the country, including Anchorage, Alaska, Salt Lake City, and the New Madrid region of southeastern Missouri and northwestern Tennessee.
As demonstrated by the South Napa earthquake of August 24th, 2014, earthquakes remain an ongoing threat. Fortunately, the impact of large future quakes can be reduced by advances in science and engineering, improved construction practices, smart land use zoning, and better emergency response preparation.

Thomas M. Brocher, Robert A. Page, Peter H. Stauffer, and James W. Hendley II Edited by Claire M. Landowski

Graphic design by Vivian Nguyen and Jeanne S. DiLeo

Many of the efforts highlighted here are part of the USGS Earthquake Hazards Program - a key element of the National Earthquake Hazards Reduction Program.

\section{COOPERATING ORGANIZATIONS}

American Red Cross, Association of Bay Area Governments, Bay Area Rapid Transit, Bay Area Earthquake Alliance, California Department of Transportation, California Department of Water Resources, California Earthquake Association, California Geological Survey, California Governor's Office of Emergency Services, California Integrated

Seismic Network, City of Oakland Office of

Emergency Services, East Bay Municipal District, Earthquake Engineering Research Institute,

Federal Emergency Management Agency, Pacific Gas and Electric Company, Pacific Earthquake

Engineering Research Center, San Francisco

Public Utilities Commission, San Francisco State University, Southern California Earthquake Center SPUR, Stanford University, Structural Engineers Association of Northern California, University of California at Berkeley, University of California at Santa Cruz, URS Greiner Woodward Clyde Federal Services, Lettis Consultants International, Inc., and many other institutions, organizations, and firms.

For more information contact: 1-888-ASK-USGS (1-888-275-8747) http://earthquake.usgs.gov/ http://ask.usgs.gov

https://www.facebook.com/USGeologicalSurvey https://twitter.com/USGS 